Agnieszka Sojka*

Kraków

\title{
Koncepcja czlowieka na podstawie analizy polskich pieśni religijnych
}

Koncepcja człowieka jest podstawą wszelkich rozważań o wychowaniu. Mając na uwadze ów proces, punktem wyjścia, a zarazem celem, do którego się dochodzi, zawsze jest sam człowiek (wychowanek). Antropologia filozoficzna w swych rozważaniach wychodzi od faktu ludzkiego i zmierza do odpowiedzi na pytanie, co w ogóle oznacza bycie człowiekiem? Jak zauważa Stanisław Kamiński, filozofia człowieka, ujmując go całościowo oraz w relacjach, w jakich pozostaje do innych bytów (gatunku, społeczeństwa, kultury, przyrody, ponadczasowych wartości, Absolutu), dopiero może zrozumieć istotę ludzką ${ }^{1}$. Antropologia filozoficzna podejmuje zagadnienie struktury człowieka jako całości fizyczno-psychiczno-duchowej. Uczeni zajmujący się tą problematyką prowadzą badania nad sprawą istoty człowieka, jego natury (czy posiada jakąś stałą naturę) oraz problemem relacji człowieka do świata go otaczającego i rzeczywistości transcendentnej, do Absolutu. Ukazując integralną wizję człowieka, próbują odpowiedzieć na pytania, z którymi nie uporały się nauki empiryczne. W niniejszym artykule odwołuję się do sposobów definiowania człowieka przez różnych myślicieli oraz ukazuję wizję zarysowaną w tekstach polskich pieśni religijnych. Problematykę tę próbuję usytuować w relacji do procesu wychowania, którego człowiek jest podmiotem.

\section{Czowiek jako istota ludzka}

W jednym ze szkiców, poświęconych wartości człowieka, Władysław Stróżewski napisał: „co znaczy «człowiek»? Nazwę tę traktować możemy wielorako:

* Dr Agnieszka Sojka, adiunkt w Instytucie Pedagogiki Uniwersytetu Jagiellońskiego.

${ }^{1}$ S. Kamiński, O koncepcjach filozofii człowieka, Zeszyty Naukowe KUL, nr 4, Lublin 1970, s. 18. 
jako określenie gatunku (człowiek w ogóle), w tym, w szczególności, pewnego gatunku biologicznego (homo sapiens), ale także jako nazwę indywidualną, jak choćby w słynnym powiedzeniu Piłata: «oto człowiek». Zastanówmy się, z którym z tych znaczeń możemy powiązać kwalifikację najwyższej wartości. Biorąc pod uwagę człowieka «w ogóle», możemy przede wszystkim zwrócić uwagę na jego wyjątkowe miejsce w świecie istot żywych czy w całej hierarchii bytów. W pierwszym przypadku zauważymy, że miejsce człowieka jest szczególnie istotne. Sam zdał sobie zresztą sprawę z tego, nazywając samego siebie «człowiekiem mądrym»-homo sapiens. Moment mądrości i warunkująca go rozumność [...] zostały tym samym wysunięte na czoło: jako to, co decyduje o człowieczeństwie człowieka i co odróżnia go od zwierząt. Na tym jednak charakterystyka miejsca człowieka w świecie nie musi się jeszcze zakończyć. Gdybyśmy pozwolili sobie na uwzględnienie i tej tradycji, w której człowiek widzi siebie jako homo metaphysicus czy homo religiosus, znajdziemy jeszcze inne potwierdzenia jego wyjątkowości. Tak na przykład w Psalmie 8: / Cóż jest człowiek, że pamiętasz o nim, / syn człowieczy, że go nawiedzasz? / Uczyniłeś go niewiele mniejszym od niebieskich mocy, / chwałą i blaskiem ukoronowałeś go. / Postawiłeś go władcą nad dziełami rąk Twoich, / wszystko poddałeś pod stopy jego" (przekład Czesława Miłosza) $)^{2}$. Autor wskazał na dwa, co najmniej, momenty istotnościowe, wskazujące, czym człowiek jest, mianowicie na wyjątkowość jego miejsca w świecie innych stworzeń oraz jego wewnętrzną predyspozycję, jaką jest religijność - potrzeba Absolutu.

Władysław Szewczyk porusza problem definicji człowieka, dzieląc próby definiowania na dwie grupy: według definicji klasycznej i definicji opisowej ${ }^{3}$. Pierwsza z nich, autorstwa Arystotelesa, ujmując człowieka jako zwierzę rozumne, podaje rodzaj najbliższy i różnicę gatunkową. Podkreślona jest w niej dwuwymiarowość człowieka, jego cielesność i psycho-duchowe ,ja”. Arystoteles używa słowa entelecheia, co oznacza zasadę życia, duszę (gr. telos - cel, eu - w, echein - mieć, „mieć cel w sobie”) ${ }^{4}$. Przechodząc z kolei do drugiej grupy definicji, przyjrzeć się trzeba tym, które ujmują różne aspekty człowieczeństwa i w ten sposób próbują opisać naturę człowieka. Sokrates rozumiał człowieka jako istotę poszukująca nieustannie siebie poprzez rozważanie warunków swego istnienia $^{5}$. Znane powszechnie jest sformułowanie Arystotelesa - człowiek jest istotą społeczna, przez co autor podkreśla jego społeczny wymiar ${ }^{6}$. Św. Augustyn ujął człowieka jednym słowem - jako tajemnicę. W wieku XVIII Giambattista Vico, uczony włoski, nazwał człowieka - homo esteticus (homo aestheticus) - miłośnik

\footnotetext{
${ }^{2}$ W. Stróżewski, $W$ kręgu wartości, Kraków 1992, s. 34.

${ }^{3}$ W. Szewczyk, Kim jest człowiek. Zarys antropologii filozoficznej, Tarnów 1998, s. 38-45.

${ }^{4}$ W. Tatarkiewicz, Historia filozofii, t. I, Warszawa 1988, s. 114.

${ }^{5}$ Tamże, s. $72-78$.

${ }^{6}$ Por. E. Aronson, Człowiek istota społeczna, Warszawa 1997.

${ }^{7} \mathrm{Za}$ : W. Szewczyk, dz. cyt.
} 
piękna ${ }^{8}$. Egzystencjalizm, któremu pytania o sens ludzkiego życia wyznaczały kierunki poszukiwań, pozostawił określenie Sørena Kierkegaarda - „istota przeżywająca siebie, swoje bycie" ${ }^{\text {" }}$. Następne przytoczone definicje ujmują pierwiastek transcendencji człowieka. Rudolf Otto, w książce poświęconej analizie świętości, podkreśla religijny charakter jako podstawowy wymiar człowieczeństwa ${ }^{10}$. Człowiek staje wobec bóstwa w postawie lęku mającego swe źródła w tajemnicy lub w postawie zachwytu (misterium tremendum, misterium fascinosum) ${ }^{11}$. Inny aspekt możliwości przekraczania siebie zawarty jest w koncepcji człowieka odpowiedzialnego Viktora Frankla ${ }^{12}$. Autor podkreśla w niej pokonywanie determinant popędowych i środowiskowych przez człowieka, jako istotę transcendująca siebie. Element niewystarczalności natury ludzkiej oraz brak pełni znalazł wyraz w określeniu Gabriela Marcela homo viator - człowiek w drodze ${ }^{13}$. Istotą człowieka jest nieustanne stawanie się, ulepszanie, dążenie do doskonałości, które tkwią w nim jako tworze dynamicznym. Ustawiczny rozwój, obejmujący całego człowieka, zawiera się również w jego twórczości, skierowanej do wewnątrz (proces tworzenia siebie, swej osobowości) oraz twórczości zewnętrznej. Stąd pojawiło się określenie homo creator, użyte m.in. przez Bogdana Suchodolskie$\mathrm{go}^{14}$. Na zakończenie przywołajmy definicję opisową Maxa Schelera nazywającą człowieka ens amans - istota kochająca ${ }^{15}$. Stoi ona na przeciwstawnym biegunie do definicji Arystotelesa animal rationale, która otwierała ów przegląd. W swej treści akcentuje ona uczucia, wolę, dążenia.

W oparciu o przytoczone definicje można ukazać koncepcję człowieka, dopełniając ją nowymi elementami z dzieł innych jeszcze myślicieli. Punktem odniesienia owych rozważań jest stwierdzenie Arystotelesa, rozwijane później przez Św. Tomasza, iż człowiek jest jednością psychosomatyczną duszy i ciała. W myśl owej koncepcji, człowiek należy z jednej strony do świata przyrody poprzez czynnik materialny czyli ciało, ale ma zdolność jej przekraczania przez drugi swój element, jakim jest forma - dusza. Wobec tego skupić należy uwage na czynnikach wchodzących w skład struktury człowieka, mianowicie na materii oraz formie. Pierwszy z nich jako czynnik określany, kształtowany to ciało, drugi - sprawiający, że byt staje się bytem indywidualnym - to dusza. Stanowią one jedność poprzez owo odnoszenie się do siebie, choć są różne. O przyczynie tej jedności mówi nam tomistyczna koncepcja człowieka. Św. Tomasz wskazuje na duszę rozumną jako jedyną zasadę kształtującą i konstytuującą ludzkie ciało.

${ }^{8}$ Tamże, s. 43 oraz I. Wojnar, Teoria wychowania estetycznego - zarys problematyki, Warszawa 1980, s. 136.

${ }^{9}$ Tamże, s. 44.

${ }^{10}$ R. Otto, Świętość, Wrocław 1996.

${ }^{11}$ Tamże, s. 39-55 i 59-67.

${ }^{12}$ V. Frankl, Homo patiens, Warszawa 1984, s. 267.

${ }^{13} \mathrm{G}$. Marcel, Homo viator, Warszawa 1984.

${ }^{14}$ W. Szewczyk, dz. cyt., s. 43.

${ }^{15}$ M. Scheler, Istota i formy sympatii, Warszawa 1986. 
Sprawia ona, że człowiek żyje, doznaje zmysłowo, poznaje umysłowo i podejmuje wolne decyzje. Związek ciała $z$ duszą ma charakter substancjalny i poprzez to obydwa elementy tworzą jedną osobę.

Rozważania nad człowiekiem jako osobą podejmował m.in Romano Guardini, podkreślając, iż człowiek odkrywa siebie jako istotę „o-sobną” zdolną rozumieć samą siebie w swojej jedyności i niepowtarzalności, w oryginalności i niezamienialności z innymi ${ }^{16}$. Klasyczna definicja Boecjusza mówi, że osoba to indywidualna substancja natury rozumnej. Wyjaśniając kolejne człony tak sformułowanej definicji, stwierdzić można, że osoba to byt istniejący w sposób indywidualny, wyposażony w rozum. Autor powyższego sformułowania pozostawał jeszcze w kręgu substancjalnego myślenia greckiego, które zostało przezwyciężone i dopełnione poprzez chrześcijańską koncepcję osoby jako bytu relacyjnego. Osoba rozumiana egzystencjalnie pozostaje w relacji do drugiej osoby, współistnieje we wzajemnym otwarciu się na siebie. Jak twierdził chrześcijański egzystencjalista G. Marcel, byt tworzy się w momencie otwarcia na drugą osobę. Nasze istnienie jest zawsze wspólistnieniem. Podkreślony zostaje w tym miejscu wspólnotowy charakter istnienia osoby ludzkiej, a zarazem wymieniany już wcześniej wymiar społeczny. Owo skierowanie człowieka do innych - na drugiego człowieka - wiąże się także z transcendencją osoby w układzie horyzontalnym oraz wertykalnym, jako odniesienie go do Absolutu.

Wracając do definicji Boecjusza, odnieść się powinno do dwóch pozostałych elementów, a więc rozumności i indywidualności. Pierwszy z nich można nazwać konstytutywną cechą osoby ludzkiej i ująć jako zdolność do myślenia, rozumowania i szerzej do miłowania. W tym znaczeniu osoba jest podstawą wszelkich aktów wolnych i rozumnych. Na podstawie wymienionych umiejętności człowiek może dokonywać wyborów w swoim osobistym życiu, w każdej jego sferze, zajmując w ten sposób pewne stanowiska wobec siebie samego i otaczającego świata. Fakt wolności, używając określenia R. Guardiniego, jest najbardziej charakterystycznym aspektem człowieka jako osoby i wiąże się zawsze z odpowiedzialnością wynikającą z konsekwencji wolnych wyborów opartych na refleksji rozumu. Człowiek, jako istota wolna i rozumna, może poznawać prawdę o świecie, a tym samym o sobie samym, innych, w końcu o Absolucie. Człowiek eksplorując otaczający go świat, ma możliwość wybierania wśród różnorodnych atrakcyjnych ofert tego, co uważa dla siebie za dobre, a zarazem tego, co w poznaniu jawi się mu jako prawda. W tym miejscu wyraźnie pojawia się następny element świata istot ludzkich, a mianowicie wartości.

Rozważając temat wolności, sytuuję go w problematyce antropologicznej jako fakt, który thumaczy ludzką egzystencję. Z jednej strony świadczy ona o autonomii jednostki, z drugiej - odnosi się zawsze do szerszego kontekstu społecznego, istnienia człowieka we wspólnocie. Oznacza to nic innego, jak zaistnienie jej w relacji do drugiego, w sytuacji dialogicznej, gdzie mamy do czynienia z drugim człowiekiem, wobec którego stwierdzamy o swojej wolności i doświadczamy

\footnotetext{
${ }^{16}$ R. Guardini, Świat i osoba, Znak, Kraków, 1969, s. 166-184.
} 
jej istoty. Bycie wolnym to $\mathrm{z}$ jednej strony dany człowiekowi atrybut, $\mathrm{z}$ drugiej postulat, zadanie związane $\mathrm{z}$ umiejętnym posługiwaniem się ową cechą. Zaznaczyć trzeba, iż wolność należy podporządkować rozumowi, który - jak stwierdzono wcześniej - poznaje prawdę, a tym samym odróżnia to, co jest prawdziwe od tego, co fałszywe. To dzięki rozumowi człowiek jest w stanie podjąć decyzję adekwatną do sytuacji, w której się znajduje.

I tu jest miejsce dla pedagogiki oraz wychowawcy, który w swych zamierzeniach i poczynaniach powinien brać pod uwagę przede wszystkim tę, jakże delikatną, bo skorą do wypaczeń, sferę człowieczeństwa. Obok wychowania pojawia się problem samowychowania, które jest nieodzowne w odpowiedzi na pytanie, kiedy człowiek staje się rzeczywiście i prawdziwie wolny? ${ }^{17}$ Aby w pełni mówić o wolności, należy wziąć pod uwagę zarówno możliwość podejmowania decyzji i dokonywania wyborów, jak pisze Zofia Matulka, zgodnych z tym, co powinno być wybrane ${ }^{18}$. Podstawą wydaje się być jednak świadomość tego, czym jest wolność jako wartość w ogóle, oraz jak urzeczywistniana jest w jednostkowym życiu ludzkim. Kolejny atrybut stanowi niepowtarzalność osoby ludzkiej, która powinna znaleźć się w centrum wszelkich innowacji pedagogiczno-wychowawczych. Wobec tego niepowtarzalność i podmiotowość osoby interpretuję na gruncie personalizmu chrześcijańskiego, idąc za myślą wspominanego już św. Tomasza z Akwinu oraz Emmanuela Mouniera i Jacquesa Maritaina. Akwinata, idąc za myślą Boecjusza, upatruje rozważane tu atrybuty człowieka w sposobie jego istnienia samodzielnego i autonomicznego. Rozważania te rozwija J. Maritain, mówiąc, iż człowiek ,jest światem samym w sobie, jest raczej całością niż częścią, raczej niezależny niż poddany i choć jest maleńką cząstką materii istniejącą w sobie, komunikuje się z istotą Absolutu, jest śmiertelnym ciałem o wartości wiecznej, jest źdźbłem słomy, które wnika w niebo" "19. Podejmuję tu wątek, interesujący w kontekście analizy tekstów religijnych, odniesienia istoty ludzkiej do istoty Absolutu. Koncepcja człowieka, według J. Maritaina, ujęta jest w kategorii bytu otwartego na Boga i na świat, bytu będącego nosicielem wartości ludzkich i Boskich dla świata. W pełni osobą staje się poprzez nieustanne zdobywanie wolności na drodze podejmowanego wysiłku moralnego oraz w działaniu zorientowanym na wartości. Ważkim elementem w koncepcji J. Maritaina, ale i w całym personalizmie jest wolność. Cytowany autor rozumie ją jako autentyczną wolność odpowiedzialną. Jest to w jego rozumieniu postawa moralna człowieka wyrażająca się w umiejętności samoopanowania, samokierowania i samodoskonalenia, umożliwiająca ciągłe współtworzenie siebie. Według E. Mouniera ${ }^{20}$,

${ }^{17}$ Por. Z. Matulka, Wychowanie do wolności jako podstawowy problem pedagogiczny, w: Pedagogika ogólna. Problemy aksjologiczne, red. T. Kukołowicz, M. Nowak, Lublin 1997, s. 243-249.

${ }^{18}$ Tamże, s. 244.

${ }^{19}$ L. A. Nowicki, Koncepcja człowieka J. Maritaina i Jana Pawła II, w: J. Maritain - prekursor soborowego humanizmu, Lublin 1992, s. 34.

${ }^{20}$ M. Montani, Il „personalismo” di Mounier e la crisi culturale, Rassegna di pedagogia, gennaio-giugno 2000. 
człowiek, będąc ciałem i duchem, powołany jest do przekraczania samego siebie. Osoba jest ze swej natury skierowana na świat, na drugiego człowieka i na Boga („,byt dla”, „byt z”). E. Mounier podkreśla, że człowiek istnieje, o ile istnieje dla drugich - bycie oznacza miłowanie. Realizacja człowieka dokonuje się we wspólnocie. Koncepcja osoby według tegoż personalisty koresponduje również $\mathrm{z}$ wizją zawartą $\mathrm{w}$ tekstach pieśni poddawanych analizie. Punktem wspólnym jest postulat nieustannego tworzenia się osoby ludzkiej - doskonalenia, wzbogacania, rozwijania życia duchowego.

Do personalistycznej koncepcji człowieka nawiązuje warstwowa teoria wychowania zaproponowana przez Stefana Kunowskiego. Traktuje on człowieka jako organizm psychofizyczny, jednostkę społeczną, byt włączony w tradycję kulturową i członka królestwa duchów ${ }^{21}$.

Zastanawiając się nad człowiekiem jako wartością, powołuję się na myśl M. Schelera oraz Ingardenowską koncepcję człowieka jako istoty aksjologicznej. Według tych koncepcji, człowiek to całość zwarta i spójna, to jedność ciała, duszy i ducha ${ }^{22}$. Pierwszy filozof przedstawia człowieka - osobę jako wykraczającego poza życie i kierującego się w stronę Boga. Bierze pod uwagę możliwość radykalnej, wewnętrznej przemiany osoby, co wiąże z atrybutem wolności ${ }^{23}$. Jak podkreśla Roman Ingarden, człowiek jest siłą, która siebie twórczo rozwija poprzez urzeczywistnianie wartości ${ }^{24}$. Jest twórcą wartości, skierowanym w stronę sfery idealnej ${ }^{25}$. Istnienie człowieka poprzez kategorię wartości rozważa również W. Stróżewski ${ }^{26}$, formułując stwierdzenie, że „człowiek istnieje wartościowo”. Gdyby zastanowić się nad taką koncepcją człowieka, a właściwie rolą wartości, którymi życie jednostki jest nasycone czy prześwietlone, jak powiada autor, ma się do czynienia z istnieniem poprzez realizację wartości. Życie ludzkie nabiera znaczenia w procesie urzeczywistniania wartości, w ten sposób człowiek uwartościawia osobiste życie. W. Stróżewski zaproponował także specyficzną strukturę człowieka nazwaną strukturą aksjologiczną ${ }^{27}$. Autor napisał: „Propozycja ta zakłada, że człowiek nie jest tworem aksjologicznie jednolitym, że realizują się w nim rozmaite dobory różnorodnych wartości, prowadzące do różnych ich ukła-

${ }^{21}$ Zob. S. Kunowski, Proces wychowawczego rozwoju czlowieka, w: Być człowiekiem i chrześcijaninem, red. B. Bejze, Warszawa 1980, s. 387.

${ }^{22}$ M. M. Baranowska, Obraz człowieka wedtug Schelera i Ingardena, Kwartalnik Filozoficzny, 1988 , z. 4.

${ }^{23}$ Tamże, s. 48 i 52.

${ }^{24}$ Por. R. Ingarden, Ksiażeczka o człowieku, Kraków 1972, s. 22-26; W. Cichoń, WartościCzłowiek - Wychowanie, Kraków 1996, s. 74.

${ }^{25}$ Por. M. M. Baranowska, dz. cyt., s. 53-54.

${ }^{26}$ Por. W. Stróżewski, Transcendentalia $i$ wartości, w: tenże, Istnienie $i$ wartość, Kraków 1982, s. 73-85.

${ }^{27}$ Zob. tenże, Aksjologiczna struktura człowieka, Kwartalnik Filozoficzny, 1998, z. 4, s. $21-46$. 
dów (systemów)"28. Autor wysunął tezę o wpływie owej aksjologicznej struktury na osobowość jednostki, co z wychowawczego punktu widzenia jest istotnym zagadnieniem. Pojęciem struktury człowieka zajmował się wcześniej Władysław Cichoń, analizując ją jako kategorię ontologiczną. Podjął on próbę uchwycenia dostępnych poznawczo elementów konstytutywnych człowieka wraz z „momentami współtworzącymi go"29.

\section{Homo religiosus na podstawie analizy tekstów pieśni religijnych}

Polskie pieśni religijne, jako utwory literackie, kreują świat wartości, podejmując tematykę życia ludzkiego w aspekcie zarówno duchowym, jak i psychofizycznym. Ukazując świat, a w nim miejsce człowieka, wyraźnie opowiadają się za określoną hierarchią wartości oraz koncepcją życia, którą można nazwać religijną. Obraz rzeczywistości jawi się w nich w aspekcie wartości, dlatego też jest to rzeczywistość wartościowa. Szerzej ujmując to zagadnienie, można mówić o koncepcji człowieka istniejącego wartościowo. W niniejszym artykule przyjmuję twierdzenie, że człowiek istnieje „wartościowo" ${ }^{30}$, co oznacza stałe urzeczywistnianie przez niego wartości poprzez wybory jednych i rezygnację z innych. Wychowania nie można oddzielić od „uczenia” wartości. Człowiek w procesie wychowania zawsze dokonuje wyborów i zarówno dotyczy to wychowawcy, jak i wychowanka. W wyborze najczęściej kieruje się przyjętą z góry, ustaloną hierarchią wartości i wedle niej postępuje.

Rozważając zagadnienie postawione w tytule, należy zwrócić uwagę na antropologiczne podstawy, jakie stoją u źródeł wizji zarysowanej przez teksty badanych pieśni. Ujawnia się w nich wyraźna koncepcja człowieka, która, jak wiadomo, ma być podstawą wszelkiej działalności wychowawczej. W niej tkwi potencjał wychowawczy analizowanych utworów. Propozycja owa charakteryzuje się realizmem $\mathrm{w}$ rozumieniu tomistyczno-arystotelesowskim ${ }^{31}$; jest to realistyczna wizja człowieka, osadzona na znajomości istoty ludzkiej. Jej bogactwo zawiera się w ujęciu zarówno potencjału tkwiącego w jednostce ludzkiej, jak i zagrożeń, na które jest narażona. Koncepcja skierowana na człowieka proponuje różnorodne wartości oraz ich hierarchię uporządkowaną od najniższych ku najwyższym. Celem wychowania jest doprowadzenie wychowanka do sytuacji, w której będzie on w stanie świadomie rozeznać, które z nich są rzeczywiście najwyższe w hierarchii. Człowiek, dokonując wyborów wartości, narażony na sprzeczność pomiędzy nimi, zawsze może przewartościować je w sobie. Tym samym zostaje przezwyciężony fakt słabości człowieka narażonego na błędy i ich

\footnotetext{
${ }^{28}$ Tamże, s. 21-22.

${ }^{29}$ W. Cichoń, Wartości-Człowiek - Wychowanie, Kraków 1996, s. 87-89.

${ }^{30}$ Por. W. Stróżewski, Istnienie..., s. 84.

${ }^{31}$ Por. E. Gilson, Realizm tomistyczny, Warszawa 1968.
} 
nieodwracalność. Zaproponowaną koncepcję można scharakteryzować jako wymagająca, ale jest to także optymistyczna wizja człowieka. Pierwszy rys wynika z nacisku kładzionego na rozwój i doskonalenie się jednostki, na urzeczywistnianie pełni swego człowieczeństwa, co wiąże się z przezwyciężaniem samego siebie. Optymizm wynika przede wszystkim z realistycznej wizji człowieka, z prawdy o nim samym. Istota tej myśli tkwi w znanych określeniach: „Człowiek jest tylko człowiekiem” oraz „Człowiek jest aż człowiekiem”. Sformułowania te wskazują na słabość, kruchość istoty ludzkiej, jej niewystarczalność, a z drugiej strony, wyniesienie jej nad inne byty, jej potencjalność oraz perspektywę, kim człowiek może być, realizując czy urzeczywistniając wartości najwyższe.

W tekstach pieśni jawi się obraz człowieka, którego najogólniej można określić jako homo religiosus, a zarazem - człowieka świadomie przeżywającego swe istnienie jako wartościowe. Powyższe sformułowania szczegółowo zostają uściślone w konkretnych kategoriach opisujących człowieka oraz poprzez szereg wartości wymienionych wprost w tekstach pieśni ${ }^{32}$. Kategorie opisowe prowadzą ostatecznie do nazwania określonych wyborów, działań, a także samych wizji życiowych. Człowiek religijny, posiadający z natury w swym wnętrzu potrzebę doświadczania Sacrum oraz transcendencji, to jeden ze wzorów homo religiosus. Człowiek jest tu istotą poszukująca, jednakże jak gdyby po omacku, bez wyraźnie sprecyzowanego celu, doświadczając wszelakich wartości, ale nie dość wyraziście uporządkowanych, na przykład wedle określonej hierarchii. Głębszy wymiar homo religiosus dotyka już istoty przeżycia religijnego, a mianowicie doświadczenia wartości Sacrum jako wartości religijnej. W chrześcijaństwie nazywa się to nawróceniem poprzez doświadczenie Boga Żywego (Osoby) i nawiązania z Nim relacji osobistej. Przeżycie religijne, obejmujące całego człowieka oraz głęboko i silnie dotykające samego jestestwa, pozostawia na nim niezatarte piętno. Człowiek religijny na tym poziomie świadomie odpowiada na wewnętrzne pragnienia doświadczenia Sacrum oraz przeżywa wartości religijne, jako realizację przekraczania ludzkiej natury obdarzonej słabością i niewystarczalnością. W tym wymiarze człowiek, określany jako homo viator ${ }^{33}$, znalazł cel ostateczny, nadał swemu życiu kierunek i stara się nie opóźniać osiągnięcia celu. Świadomy jest swej drogi i przekonany wewnętrznie, iż realizowanie celu prowadzi go do dobra. Owo dobro może być pojmowane na różne sposoby i często zależy ono po prostu od przyjętej przez danego człowieka hierarchii wartości, od tego, jaka wartość jest dla niego naczelną i według której, z wielu różnorodnych wartości, dokonuje on swych wyborów, oraz wokół której koncentrują się pozostałe wartości. Dla człowieka religijnego, który jawi się z tekstów polskich pieśni religijnych, wartością najwyższą a zarazem dobrem jest Bóg. W sytuacjach wyborów dnia codziennego, przed którymi stoi homo religiosus, głównym kry-

${ }^{32}$ Por. A. Sojka, Wychowawcze funkcje polskich pieśni religijnych powstatych po 1945 roku, Paedagogia Christiana 2005, nr 2 (16).

${ }^{33}$ Por. G. Marcel, dz. cyt. 
terium wartościowości staje się dobro najwyższe. Nawiązać można do powinnościowego charakteru wartości, czyli do perspektywicznego ich wymiaru, wskazującego przyszłość. Gdy w wychowaniu mówi się o człowieku i koncentruje się uwagę wychowanka na wartościach, które w tym wypadku mogą być celami wychowania, odnosi się je do pewnego wzoru, ideału, wedle którego projektuje się wychowanie i który chce się osiagnąć w owym procesie. Nie zatrzymuje się tym samym na znajomości wychowanka takiego, jakim jest aktualnie, ale wytycza drogę jego rozwoju, widząc go takim, jakim może być lub jakim powinien się stać. Z tekstów wyłania się obraz człowieka, który jest takim, jakim powinien być. Decyduje o tym choćby wiara, z jaką podmiot wyraża się o swej relacji do Boga. Wybory, które koncentrują się na wartości dobra, na Bogu, są decyzjami wewnętrznymi, obejmującymi całego człowieka przekonanego o ich słuszności, ale otwartego na krytyczne opinie i potrafiącego bronić swoich racji. Odpowiedź to wybór każdego jednostkowo potraktowanego człowieka. Życie istot ludzkich wyznaczone przez podejmowane decyzje nie zostaje w tej perspektywie przez nie zdeterminowane. Życie jako dar nie jest ograniczone ślepym losem i - choć poszczególne wybory ludzkie naznaczone są konsekwencją i odpowiedzialnością - to nie oznacza to, iż zamykają one człowieka na wizję szczęścia proponowaną w tekstach pieśni religijnych.

miłości dar, Twego Ciała znak

łączy nas i przemienia życia szare dni.

Jak deszcz dotykiem swoich łez

na świat strumienie życia śle

miłości dar, Przenajświętszej Krwi

zbawia nas, daje siłę aby lepiej żyć /pieśń Uwielbienie/

A kiedy tonę i z drogi zbaczam,

gdy wstydem płonę, On mi przebacza. /pieśń Pan wołal

Nie wystarczy odbić od portu swych żądań

i skryć w obcej twarzy strzaskaną swą twarz.

[...] Dopomóż jak zrozumieć dawnych modlitw treść

w zapomnianych miejscach ze sobą spór wieść.

Obdarz nas powrotem do rzuconych gniazd,

od konarów wzruszeń wrażliwości słów.

Może starczy spojrzeć w przeszłości ołtarze,

znów stanąć na progu otwartych wciąż drzwi. /pieśń Matko wracających/

Człowiek, żyjąc w świecie, doświadczając różnego rodzaju wartości, na swój sposób przeżywając je, odpowiada na swoje powołanie. Powyższe stwierdzenie nie byłoby jednak pełne bez dopowiedzenia, że człowiek - wedle nauki Kościoła katolickiego - jest w swojej istocie nastawiony na życie w świętości. Przekonuje się o tym w momencie doświadczenia kruchości życia, niewystarczalności wobec 
wciąż nowych obszarów egzystencji. Chodzi tu o pogłębienie wrażliwości, by uzdolnić wnętrze człowieka do odnalezienia w sobie samym wartości Sacrum.

Pieśni religijne już samą nazwą swej formy wskazują na kierunek wyznaczony w sferze treści. Jest to określony sposób patrzenia na świat, życie oraz człowieka, uwzględniający w nim istnienie Osoby Boga. Pieśń może dostarczać również wzorów osobowych.

Analiza repertuaru pieśniowego ukazała świat wartości wykreowanych w utworach literacko-muzycznych. Pieśń religijna jest przekaźnikiem konkretnych wartości, które odnoszą się do wychowania jako procesu „uczenia” wartości. Wyłonione z tekstu dziedziny wartości (np. moralne) są egzemplifikowane przez poszczególne wartości (np. uczciwość). I tak, mając do czynienia $\mathrm{z}$ dziedziną wartości moralnych, stwierdzono pojawianie się $\mathrm{w}$ tekstach pieśniowych wierności, wytrwałości, męstwa, odpowiedzialności. Pieśni przedstawiają sytuacje, w których znajdować się może człowiek, stawiają pytania dotyczące egzystencji ludzkiej, odnoszące się szczególnie do moralnej kondycji człowieka. Przedstawiane są również konkretne osoby jako wzory do naśladowania. Są to postaci historyczne, ludzie charakteryzujący się realizmem życiowym, świadomi swego celu życia, odnajdujący jego sens i walczący o nie. Konstrukcja taka pozwoliła na wyinterpretowanie z materiału badawczego konkretnych postaw wcielonych w życie. Są to propozycje postulowane przez autorów tekstów, które można zaakceptować lub odrzucić, a nade wszystko podjąć refleksję nad nakreśloną wizją świata - religijna, a zarazem humanistyczna, w której życie jawi się jako wartość pierwszorzędna, a kryterium wyborów stanowi miłość rozumiana jako akt wolnej woli jednostki. Skierowana jest ona na pragnienie i realizowanie dobra drugiego człowieka - bliźniego:

żyję, każdego dnia znajduję w radości miłowania

moją wolność /pieśń Już znalazłam mój skarb/34.

Chcę dobroć siać, chcę miłość dać /pieśń Jeżeli chcesz/

Tak wiele problemów szarpie ludzi dziś,

do nich mnie posyłasz, im Twą miłość nieść. /pieśń Razem Ty i jal

W tym miejscu poświęcę uwagę analizie konkretnych wartości, których wspólny zestaw składa się na postawy życiowe, świadczące o dojrzałości jednostki.

W postawach, jakie rysują się w tekstach analizowanych pieśni, interesują mnie szczególnie cierpliwość i wytrwałość jako wartości osobowe oraz męstwo i dzielność z wartości moralnych. Wartości owe rozumiane jako sprawności i zarazem cnoty są tymi, które warunkują bezpośrednio osiąnnięcie przez człowieka

${ }^{34}$ Cytowane pieśni pochodzą ze zbiorów własnych Zgromadzenia Sióstr Uczennic Boskiego Mistrza w Częstochowie. 
jego dojrzałości psychicznej i duchowej, co z kolei jest najwyższym celem wychowania. W sytuacjach ekstremalnych, gdy człowiek odczuwa zagrożenie, nie jest pewien położenia, w jakim się znalazł czy doświadcza nowych warunków, najwyraźniej może skonfrontować się z sobą samym i konkretnym momentem na drodze osiagania pełni człowieczeństwa. Realizowanie swego człowieczeństwa jawi się tutaj jako cel, ku któremu zmierza cały proces wychowania. Każde nowe zadanie, przed którym staje człowiek, może mieć charakter wychowawczy i wskazywać, kim w danym czasie ów człowiek jest i na jakim etapie dojrzałości się znajduje.

Urzeczywistniać wartość męstwa to, najprościej ujmując, podtrzymywać wysiłki zmierzające do przezwyciężenia trudności. Analizy męstwa dokonał ks. Jacek Woroniecki ${ }^{35}$, wyodrębniając dwa czynniki: niecofanie się i wytrzymanie wobec grożącego zła oraz atakowanie go. W analizie męstwa rozumianego jako cnota, autor podkreśla znaczenie woli i rozumu, które są konieczne w podjęciu odpowiedniej postawy wobec trudności i dokonaniu wyboru jednego $\mathrm{z}$ dwóch wymienionych wyżej czynników. W taki też sposób męstwo istnieje w tekstach polskich pieśni religijnych.

Realizacja omawianych wartości ujawnia się w sytuacjach, które określić można jako trudne. Cierpienie - nieodłączny, realny fakt, wpisany w każde jednostkowe życie ludzkie - w pieśniach religijnych jawi się przede wszystkim w kategoriach wartości. Źródło takiego spojrzenia na doświadczenie trudności w życiu człowieka bierze się z chrześcijańskiej wizji świata, a więc w odniesieniu do Osoby Jezusa Chrystusa - Boga a zarazem człowieka i Jego zbawczego dzieła dokonanego przez śmierć i zmartwychwstanie. W związku z powyższym, charakterystyczna dla obrazowania cierpienia ludzkiego w pieśniach religijnych jest symbolika krzyża jako znaku trudu, ale podkreślić trzeba, że jest to trud przezwyciężony i niebędący celem samym w sobie (w znaczeniu cierpienia dla samego cierpienia), trud mający głęboki sens. Odnalezienie owego sensu cierpienia, a tym samym jego ukrytego wymiaru, jest związane z urzeczywistnieniem innej jeszcze wartości osobowej, a mianowicie głębokości myślenia.

I tak w wielu pieśniach religijnych krzyż występuje jako wartość, jawi się jako pomoc dana człowiekowi oraz przedmiot, odczytywany w świadomości ludzkiej jako wartościowy, a tym samym warty podjęcia określonych działań na jego rzecz. Posłużyć się można w tym miejscu fragmentami dwóch pieśni: Krzyżu mój, Krzyżu oraz Na skrzyżowaniu świata dróg:

Na skrzyżowaniu świata dróg

na ludzkich dróg rozstaju,

postawił krzyż swój dobry Bóg,

dla tych, co się błąkają. /pieśń Na skrzyżowaniu świata dróg ${ }^{36}$.

${ }^{35}$ J. Woroniecki, Katolicka etyka wychowawcza, t. I-II, Lublin 1986, s. 424-437.

${ }^{36}$ Exsultate Deo. Śpiewnik mszalny, wyd. VI, [bmw] 1990. 
Określenia „skrzyżowanie”, „rozstaje” użyte w cytowanej pieśni, mogą nasuwać odbiorcy skojarzenia $\mathrm{z}$ odczuwaniem przez podmiot sytuacji wyboru, rysujących się przed nim nowych perspektyw, które wymagają konkretnej zmiany, często radykalnej wobec sytuacji, w której dotychczas się znajduje. Krzyż jest ukazany jako wyraźny znak wskazujący kierunek, cel drogi. Analizowane określenia mogą mieć konotacje nieprzyjemne, czy wręcz negatywne, odwołując się do doświadczenia braku, zagubienia. Zostaje to wyartykułowane przez następujące określenia: „błąkają się”, „mgła”, „środek ciemnej nocy”. W tym kontekście krzyż ma stać się drogowskazem dla człowieka doświadczającego świadomie stanu swego „błąkania”, ale przede wszystkim dla tego, który nie nabył jeszcze pozytywnych cech umożliwiających urzeczywistnianie celów autentycznie ludzkich. Słowo „skrzyżowanie” może oznaczać rozdarcie człowieka między dobrem a złem, człowieka znajdującego się w sytuacji wyboru, który najczęściej odnosi się do realizacji własnego projektu życia. Znak krzyża symbolizuje kierunek, w tym wypadku zarówno kierunek ludzkich decyzji, jak i jedną z możliwości, szans rysujących się przed człowiekiem w momencie ich podejmowania.

Inne wartości zawarte $\mathrm{w}$ tekstach analizowanych pieśni, jakie niesie w sobie znak krzyża, to bezpieczeństwo i pewność, na które wskazują następujące cytaty:

A kiedy widzę go we mgle

lub w środku ciemnej nocy,

ramieniem swoim wspiera mnie,

udziela mi pomocy /pieśń Na skrzyżowaniu świata dróg/;

$[\ldots]$

Ty mnie ratowałeś

całe moje życie,

$[\ldots]$

na Twoich ramionach

los świata spoczywa

i też los człowieka,

który Ciebie wzywa. /pieśń Krzyżu mój, Krzyżu/

Postawy życiowe człowieka ujawniające się poprzez treści badanego repertuaru szczególnie ewokują wartość radości. Jest ona przeżywana wewnętrznie, a ujawnia się i realizuje w opanowaniu i wytrwałości wynikających z nadziei, kolejnych wartości wyłonionych na podstawie analizy pieśni.

Będę śpiewał Tobie, mocy moja!

Ty, Panie, jesteś mą nadzieją,

Tobie ufam i bać się nie będę. /pieśń Będę śpiewat Tobie, mocy moja/ ${ }^{37}$

${ }^{37}$ Pieśni chwaty, oprac. A. Sionek, E. Maier, K. Miturska, Lublin 1991. 
Na podstawie wyłonionych wartości podjęłam próbę ukazania obrazu człowieka w odniesieniu do cierpienia. Kategoriami opisującymi są w tym wypadku następujące określenia: świadomość, słabość, otwartość. Jest to przede wszystkim człowiek świadomy istnienia cierpienia, a tym samym doświadczający swojej słabości w spotkaniu z trudnościami: „Zamiast dźwigać ciężar, który inni niosą / zaparłem się Ciebie, jak Piotr ongiś nocą" (fragm. pieśni Krzyżu mój, Krzyżu). Równocześnie jest to człowiek niezatrzymujący się na etapie przeżycia własnej słabości, ale poszukujący pełnej prawdy o sobie samym. Wobec tego świadomość ta dotyczy nie tylko słabości, ale i potencjalnych możliwości tkwiących w człowieku, które jest on w stanie realizować w toku procesu wychowania. Istotną sprawą w przeżywaniu cierpienia jest odnalezienie źródła zarówno tego, co w człowieku słabe, jak i tego, co mocne, a tym samym realne uchwycenie swoich możliwości oraz rzeczywistości, w jakiej żyje człowiek. Realną wizję życia z jego trudami szczególnie akcentują pieśni i piosenki, których teksty czerpią swoje treści bezpośrednio z Biblii. Powołam się na jedną z nich pt. Mitość Chrystusa, gdzie wymienione za Św. Pawłem niedogodności losu ludzkiego, takie jak: utrapienie, ucisk, prześladowanie, głód, nagość, niebezpieczeństwo, miecz, śmierć przeciwstawione zostają wartości miłości, w perspektywie której stają się wyzwaniem podjętym dla osiagnięcia jeszcze innej wartości, a mianowicie życia. Wobec zarysowanej wizji potrzebna jest otwarta postawa człowieka zdolnego przyjąć trudności w taki sposób, że stają się one źródłem autentycznego wzrostu psychicznego i duchowego, a tym samym prowadzą do osiagnięcia dojrzałości. Postawa otwarcia wobec cierpienia jest związana z przeżyciem wartości Sacrum i stanowi odpowiedź na doświadczenie kontaktu z Absolutem na drodze osobistej relacji z Bogiem poprzez wiarę. Polskie pieśni religijne, ukazując problem cierpienia, przedstawiają konkretny wzór osobowy, ideał do naśladowania. Jest nim Osoba Jezusa Chrystusa, którego życie - będące egzemplifikacją głoszonej nauki - jawi się jako jedna z propozycji tworzenia własnego projektu życia. Analizując wartość cierpienia, należy uświadomić sobie, iż termin ten, mający konotacje negatywne, może być postrzegany jako wartość, gdy służy Dobru ${ }^{38}$. W wypadku tym występuje poszerzenie pola wartości o ,antywartość”. Cierpienie w takim ujęciu służy Dobru jako wartości najwyższej (w religii chrześcijańskiej - Bogu). Służy także człowiekowi do osiagnięcia wartości wyższych, jest środkiem do realizacji człowieczeństwa. Wzorem tak pojmowanego cierpienia jest Chrystus oraz postaci świętych.

Inną wartością również wyrazistą w tekstach religijnych jest wartość pokoju, którą za W. Stróżewskim zaliczam do dziedziny moralnych. W pieśniach źródłem i dawcą pokoju jawi się Bóg. Wartość ta eksponowana jest jako upragniona i pożądana przez każdego człowieka. Wyartykułowana została również podstawowa potrzeba istoty ludzkiej, mianowicie bezpieczeństwo.

W tekstach, gdzie mowa jest o życiu człowieka, iż powinno „być w prawdzie", wyeksponowana jest jeszcze jedna wartość. Człowiek powinien żyć w praw-

\footnotetext{
${ }^{38}$ Por. W. Stróżewski, Istnienie...
} 
dzie, co więcej pragnąć życia „,prześwietlonego światłem prawdy” - a idąc dalej w analizie tekstów - poznać prawdę to posiąść szczęście. W takim ujęciu wartość prawdy ujawnia się nie tylko jako wartość poznawcza, ale przede wszystkim jako transcendentale. Wartość ta ukazana jest w analizowanym materiale jako cel życia człowieka, jako dążenie na drodze życiowej. Prawda ujawnia się jako wartość i opisywana jest określeniami niosącymi pozytywne znaczenia, takimi jak: życie, światło, radość, wolność, dobro. Występuje wraz z innymi wartościami, które warunkuje, bo wszystkie wymienione wartości współwystępujące z nią istnieją, gdy są prawdziwie. Zarówno życie, jak i radość oraz wolność, by rzeczywiście stały się udziałem człowieka, muszą być autentyczne. Jak sformułował tę myśl W. Stróżewski: ,prawda jest ideą regulatywną rządzącą wykrywaniem faktycznego stanu rzeczy, będącego punktem wyjścia owych poczynań" 39 . W przebadanych tekstach łączy się z wartością osobową, jaką jest wolność, na co wskazuje cytowany poniżej fragment pieśni:

Przemień nasze czasy trudne

Na czas prawdy i wolności. /Jezu, Który ukazałeś ${ }^{40}$

Człowiek, przeżywając swe życie, jest narażony na różnego rodzaju zniewolenia, związane zarówno z własną kondycją, jak i otaczającym go światem zewnętrznym ${ }^{41}$. Treści pieśni wyraźnie określają ową „drogę wyzwolenia” wyzwolenia przez prawdę, wskazując na Osobę Boga. Interesujący jest sposób ujęcia problemu wolności człowieka. Chodzi tutaj o wolność wewnętrzną, o doświadczenie i przeżycie owej wartości do tego stopnia, by ją umiłować i nieustannie urzeczywistniać w sobie w „byciu dla innych”.

Analiza repertuaru pieśniowego ujawniła całościowy obraz człowieka. Celem życia jest osiagnnięcie pełni człowieczeństwa w każdym wymiarze egzystencji ludzkiej poprzez realizację wartości należących do każdej dziedziny (religijnych, moralnych, osobowych, poznawczych, witalnych, przyjemnościowych) z należnym dla każdej grupy miejscem w ustalonej hierarchii. Treści pieśni akcentują funkcjonowanie człowieka w wymiarze horyzontalnym oraz dopełniającym człowieczeństwo - wymiarze wertykalnym.

\footnotetext{
${ }^{39}$ Tamże, s. 79.

${ }^{40}$ Śpiewnik. Pieśni do Tajemnicy Przemienienia Pańskiego, Warszawa 1993.

${ }^{41}$ Por. W. Stróżewski, Medytacja o wyzwoleniu przez prawdę, w: tenże, $W$ kręgu..
} 


\section{Portrait of a Human Being on the Basis of Polish Religious Songs (Summary)}

The article is based on text research of Polish religious songs written after 1945 (after World War II). An analysis of the texts has shown the world of values and the image (the portrait) of a human being. It is a religious human being, a so-called homo religiosus, realizing in his life values of all possible fields, i.e. moral, personal, cognitive, utility and pleasure (hedonistic) ones. All the groups of values are important but each of them has its own established place in the hierarchy. The image of a human being having a relationship with another human being and with God (horizontal and vertical). 